\title{
Industry Attractiveness and Knowledge Management on the Formulation of Competitive Strategy and Partnership and Its Implication on Coffee Company Performance in Aceh
}

\author{
Muhammad Adam \\ Lecturers in Management in Economic Faculty, Syiah Kuala \\ University, Kopelma Darussalam, Banda Aceh, Indonesia. \\ E-mail: adam_usk@yahoo.com
}

\author{
Hendra Syahputra \\ Lecturer in Knowledge Management in Daôva and \\ Communication Faculty of Islamic University of Ar-Raniry, \\ Kopelma Darussalam, 23111, Banda Aceh, Indonesia. \\ e-mail: hsyahputra@gmail.com \\ Benny Gunawan \\ Ph.D.Student in Management Science, Syiah Kuala \\ University, Banda Aceh, Indonesia. \\ e-mail : bengun87@yahoo.co.id
}

\begin{abstract}
This research examined the influence of knowledge management and industry environment on coffee company performance in Aceh using competitive strategy and partnership variables as the intervening variable. This research used quantitative model conducted through descriptive and verified survey (causal relationship) which are subsequently applied in the formulation and examination of the developed hypotheses. The data was collected from the questionnaires spread to 600 top, middle and operational level managers as the observation units of 510 selected companies and was analyzed using Structural Equation Model (SEM) and processed using SEM Amos Ver. 22.0 software. This research delivered empirical evidence that the using of knowledge management variable and Industrial Organization View (IO/V) approach through industry environment variable and intervening variable, competitive strategy and partnership, as the performance booster for organization in the context of coffee industry is relatively new.
\end{abstract}

Keywords-Knowledge management, Industry environment, Competitive strategy, Partnership, Coffee company performance, Knowledge management, Coffee Firm.

\section{INTRODUCTION}

The development of world coffee industry is inseparable from the substantial role of coffee company. The opportunities for rapidly growing company, which are unpredictable and complex in nature, have led to various conflicts within coffee company [1]. This change not only created by industry environment but also by the company itself, such as coffee company in Indonesia. In a high rapid environment, making an innovative network and knowledge management for a company is an important matter.
Various challenges are directly facing by coffee company in Indonesia nowadays, like the increasing of people awareness who involved in this business, the increasing of competition and its product quality, the increasing of production cost due to the increasing use of information technology, and other environmental factors including resources, activity and result management.

The most significant development in these few decades is the emergence of Indonesia as the third largest coffee producer countries in the world where Aceh gave a valuable contribution to this achievement [2]. Unfortunately, since Aceh coffee used to be exported via North Sumatera, the name is indiscernible and thus not listed as one of the largest coffee exporter provinces in Indonesia.

Presumably, this condition is emerged due the weaknesses of coffee industry in Aceh to collaborate and partner with other parties [3]. Therefore, strengthening the partnership is very important as there is no study that uses partnership variable of coffee industry in Aceh, Indonesia, even in the world [4], as the research variable.

The business development is strongly associated with knowledge management as it is one of the most strategic resources owned by company [5]. Knowledge management enables organization exploring and developing their resource, included in coffee company [6]. Knowledge management also plays important role in the competition of creating the uniqueness to support future success. Therefore, knowledge management should be paired with other management variables, like competitive strategy and partnership which will impact on companyôs performance. 
In accordance with the development of coffee industry, knowledge management has a very important and also strategic meaning for company [7]. KM plays an important role as a dynamic dialectical element of various activities which are developed and experienced by organization. KM also extends significant contributions as the capitals for all of organization's members.

Business people, business entrepreneurs and even business units from small to large scale have to understand KM. This becomes one of the important issues that should be considered in order to keep the competition on track and to sustain good industry. A Competitive advantage is essentially derived from the value of a knowledge that is created for their customerôs outweigh the costs they spent for creating that value [8].

According to the above explanation, it is important to examine the performance of coffee company in Aceh since coffee has been one of the most potential commodities for Aceh which exists in a tight industry environment competition.

\section{LITERATURE STUDY}

\section{A. Coffee Industry in Indonesia and Aceh}

Coffee is one of the most important commodities for Indonesia, which has resulted in a great number of foreign exchange for the country as reported by the Central Bureau of Statistics. The foreign exchange generated from the coffee industry has reached USD 9.14 million and has been increased about $34.27 \%$ in 2013 compared to the same period in 2012.

Indonesia's coffee production has increased from 6987.3 tons in 2007 to 8676.6 tons in 2012 (increased about 24.18\%). World coffee demand is quite great and shows an increasing trend, characterized by high world coffee imports amounted to 6,313 tons in 2010 and increased to 6556 tons in 2012 (increased about $3.86 \%$ ). Coffee exports coffee producing countries of the world in 2010 amounted to 5815 and increased to 6789 thousand tons in 2012 (increased about $16.74 \%$ ). Thus Indonesia has a great opportunity to increase its export market. But, the performance of the coffee industry in Indonesia is remained unstable.

On the other hand, Aceh has been recognized as one of the major coffee producing areas in Indonesia, concentrate in Central Aceh and Bener Meriah. About $66 \%$ of the total farms are located in Central Aceh. Generally, the farms are owned and managed by people traditionally without proper coffee cultivation technology.

Gayo Highlands is located in the Bukit Barisan Mountains Aceh province which consists of three districts, namely: Central Aceh, Bener Meriah and Gayo Lues. Almost 95\% of the farms are Arabica, while the rest are Robusta. The Arabica coffee mainly export to Europe, Japan and the United States with a value of $\$ 17$ million in 2010 , and increased to $130 \%$ compared to 2009 with only $\$ 7.4$ million [9-10).

Yet, in terms of its development, this commodity still confront with several serious obstacles, among others: 1) Coffee is exported in the form of seeds thus the added value is not maximal; 2) the grade of coffee beans quality produced by farmers is still at the level of 3-5 (relatively low); 3) the fulfillment of the raw materials for agro-industry is not maximal, 4) the institutional aspects are not as expected to mediate all the involved actors, 5) the price received by farmers is still too low compared to the market prices, especially during the harvest. Therefore, it can be said that the current business activities have not meet the sustainable aspect in a supply chain order yet.

\section{B. Performance}

Company should make ongoing changes to develop its effectiveness. The changes are intended to find or develop ways for utilizing the existing resources and capabilities to enhance the ability of creating values and improving last long performance. Initially, there are only financial criteria which is used to rate the excellences of a company performance.

Performance is served as an instrument to determine whether the company is able to sustain its life (going concern) and the basis for formulating the company's operational planning in the future as well as the information for shareholders, stakeholders and customers, regarding the achievements and the success of the company.

\section{Partnership}

The quality of the partnership is a set of exchanges in partnership forming a behavior related to the trust, commitment, long-term oriented, mutual understanding, shared information (information sharing) and norms [11].

Partnership quality is a component of an effective and long-term cooperation among the companies which are based on trust, partnership, commitment, communication and effective conflict management. According to [12], the most often used characteristics and quality of a partnership are trust, information and commitment. Long-term partnership quality is based on several behaviors: trust, commitment and sharing information [11].

\section{Competitive Strategy}

The way organization competes in an industry is a choice of competitive strategy. There are at least three approaches that attempt to define competitive strategy, i.e.: adaptive strategy [13], business definition framework and generic competitive strategy [14].

The adaptive strategy of Miles \& Snow is based on organization's success in using strategies to adapt to an uncertain environment. In this approach, there are 4 types of strategies, i.e.: prospector, defender, analyzer, and reactor. The combination of the two become the basis for [14] to find three possible competitive strategy "differentiated", "undifferentiated" and "focus". In an approach proposed by Porter, there are two factors that are taken into account in creating the right competitive strategy. The first is based on the competitive advantage of the organization. According to Porter's competitive advantage will only be obtained through one of two sources: from the excellence of creating a low-cost (cost leadership) and from the ability to be different to competitors. The second factor is the scope of product-market (competitive scope) in which organizations compete to each other in a broad and narrow market. The combination of these 
two factors becomes the basis of Porter's generic competitive strategy, i.e.: cost leadership, differentiation, and focus (based on cost or differentiation).

\section{E. Industry Environment}

Industry environment is part of external environment that constitute to the changes that occur outside the scope of the company affecting competitive advantage and survival. $\mathrm{M}$ management experts have various different terminology concerning the industry environment, those are: competitive environment, task environment and immediate environment.

Industry environment is named as working environment (task environment), including elements or groups that directly and in turn influenced by the company that consist of government, local communities, suppliers, competitors, customers, creditors, labors, special interest groups and trade associations [12].

Meanwhile, [15] also mention it as an interrelated industry to remote environment and operating environment. Other reference call it competitive environment which consists of the buyer power, seller/supplier, threat of new entrants, threat of substitute products and the intensity of competition in the similar industry [16]. It also called immediate industry and competitive environment which include suppliers, customers, competitors, new entrants, substitute products [17]. Along with the increasing role and influence of other stakeholders beyond the 5 Forces approach developed by [18] added one more power that can affect to the intensity of industry competition that is the relative power of other stakeholders, such as governments, local communities, creditors (if not included in the elements suppliers), trade associations, special interest groups, labor associations (if not included in the elements suppliers), shareholders and complementary.

\section{F. Knowledge Management}

Knowledge Management term (hereinafter called KM) often mentioned in management jargon. This term began to be popular in the 1990s decade. This jargon continues to thrive and begin to be implemented various organizations and companies. This jargon has also contributed to emphasize the attitude of openness and readiness of new information. Every knowledge starts from an individual. When an individual knowledge can be transferred into organizational knowledge, the knowledge will be invaluable for improving the productivity of company or organization. In order to be able to transform individual knowledge into organizational knowledge, then efforts should be made on an ongoing basis at all levels within the organization.

According to some literatures, the definitions of knowledge management (KM) are described as follow:

- $\mathrm{KM}$ is organization efforts for achieving organizational goals by motivating and facilitating knowledge-worker to develop and improve their skills in interpreting the available data and information, experiences, skills, cultures, characters, personalities, etc. so as to give meaning for others [19].

- $\mathrm{KM}$ is a systematic, firmly and deliberately efforts to build, renew and apply knowledge in order to maximize the effectiveness of knowledge relationship within organization and store it as knowledge assets to be renewed continuously for the creation and innovation [20].

- $\mathrm{KM}$ is a creating, capturing and using process of knowledge to improve the performance of organization. $\mathrm{KM}$ used to be associated to two types of activities, i.e.: documenting and deciding appropriate individual knowledge and spreading them through corporate data base as well as facilitating knowledge sharing among people through groupware, e-mail and internet [21].

Nonaka introduced four processes of creating knowledge within organization, as can be seen in the picture below.

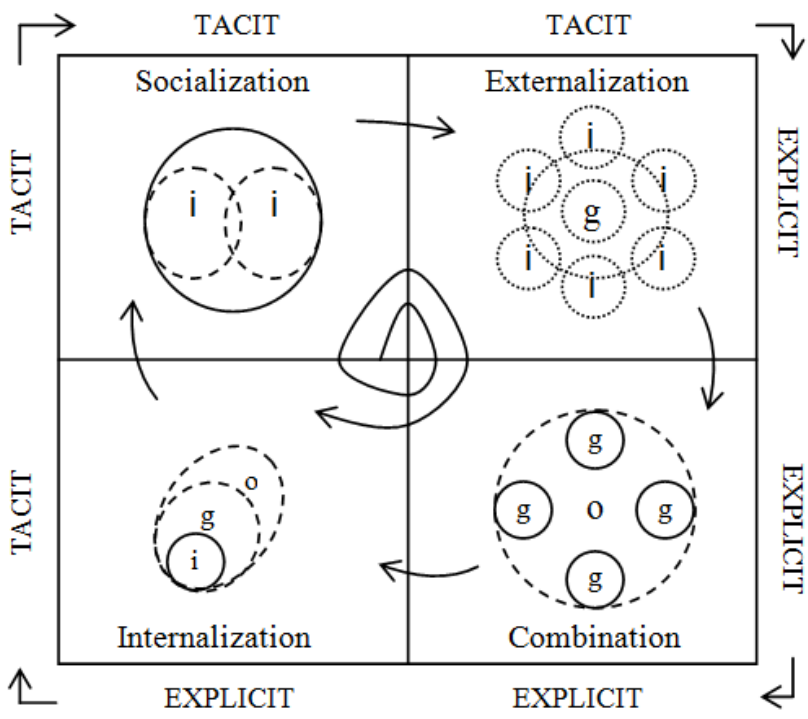

Figure 1. The knowledge spiral [22]

According to the above picture, the implementation of those process in each step can be defined as follow.

\begin{tabular}{|ccc|}
\hline $\begin{array}{c}\text { Tacit } \\
\text { knowledge }\end{array}$ & $\begin{array}{c}\text { Tacit } \\
\text { knowledge } \\
\text { Socialization } \\
\text { Tacit knowledge sharing } \\
\text { \& determination through } \\
\text { interaction \& direct } \\
\text { experience }\end{array}$ & $\begin{array}{c}\text { Tacit } \\
\text { knowledge } \\
\text { Erticulation of tacit to } \\
\text { explicit dialogue dan } \\
\text { reflection }\end{array}$ \\
Tacit & $\begin{array}{c}\text { Internalization } \\
\text { Lessons learned \& } \\
\text { acquisition which directly } \\
\text { translated to organization }\end{array}$ & $\begin{array}{c}\text { Explicit knowledge convention } \\
\text { to new explicit knowledge } \\
\text { through applying explicit } \\
\text { knowledge \&information }\end{array}$ \\
\hline
\end{tabular}

Figure 2. Knowledge creating process [22]

Below are factors that will success the implementation of $\mathrm{KM}$, i.e.:

- A trusting and open organizational culture [23-25];

- Senior management leadership and commitment [16, 24-26]; 
- Employee involvement [25, 27-29]

- Employee training [30-31];

- Trustworthy teamwork $[25,32]$;

- Employee empowerment [29, 31, 33];

- Information systems infrastructure [24-25, 33-36]

- Performance measurement [21, 33, 37-38]

- Benchmarking [38-41];

- Knowledge structure [23-24, 42-44].

The KM implementation in this research measures through questionnaires to determine whether the respective company has already implement KM in a good manner. The quality of partnership is a set of sharing that forms behaviors that related to trust, commitment, long-term oriented, mutual understanding, information sharing and norms [11]. The quality of partnership is an effective component and long-term cooperation among companies which is based on trust, commitment, communication and effective conflict control. According to [12], the most familiar characteristic and quality of partnership is trust, information and commitment.

\section{RESEARCh MethoD}

This research used survey method in which the samples are part of the population. The analysis unit was coffee companies in Aceh represented by coffee companies from Aceh Tengah and Bener Meriah, as both are the main coffee production centers in Aceh [10]. While the observation unit was people in manager level from each company as respondents to fill out the questionnaires spread. The total analysis unit is 510 coffee companies in Aceh is shown below.

TABLE I. POPULATION AND RESPONDENTS

\begin{tabular}{|c|c|c|c|c|}
\hline No & $\begin{array}{c}\text { Coffee } \\
\text { Company }\end{array}$ & $\begin{array}{c}\text { Analysis unit } \\
\text { (office) }\end{array}$ & Sample & $\begin{array}{c}\text { Total } \\
\text { Respondent }\end{array}$ \\
\hline 1 & $\begin{array}{c}\text { Aceh } \\
\text { Tengah }\end{array}$ & 300 & $\begin{array}{c}200 / 510 \times 300 \\
=118\end{array}$ & $118 \times 3=354$ \\
\hline 2 & $\begin{array}{c}\text { Bener } \\
\text { Meriah }\end{array}$ & 210 & $\begin{array}{c}200 / 510 \times 210 \\
=82\end{array}$ & $82 \times 3=246$ \\
\hline & Total & $\mathbf{5 1 0}$ & $\mathbf{2 0 0}$ & $\mathbf{6 0 0}$ \\
\hline
\end{tabular}

We used closed questionnaires and SEM Amos 22.0 Software for data analysis. The primary data collection was conducted to gather complete information about managersô perception and the undergoing phenomena through survey (observation technique, interview, and questionnaire). The data collected was by determining samples of total population of 200 managers which are proportionally determined in the chosen sub-districts. While the secondary data collection was conducted by collecting the available data, both from publication and interview in printed-media, books, reports, or electronic sources.

The research samples are 50 respondents and $\alpha=0.05$, thus the $r$ value is 0.361 . The questionnaire items with coefficient correlation smaller than its critical value will be discarded and not included in the subsequent test. This test uses Person Correlation formula.

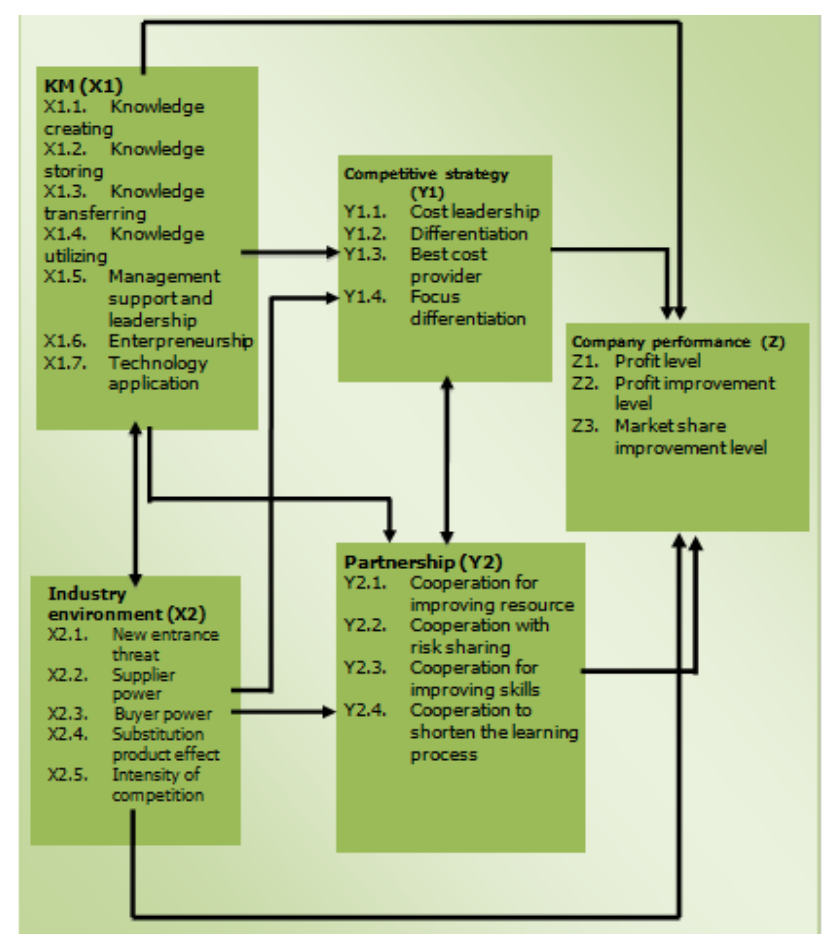

Figure 3. Research Structure Model

\section{Results AND Discussions}

The data analysis in this research conducted through two steps, i.e.: data reduction (validity and reliability) and hypothesis testing.

The flowchart of this research consists of two models, i.e. measurement and structural. Measurement model describes the validity and reliability of items in measuring dimension or research variables. This model divided into two types, i.e.: first order and second order. First order is a model in which variable is measured in a step known as variable $і$ indicator. This model was used in measuring the performance variable. The second orders or variable $\ddot{i}$ dimension $\ddot{i}$ indicator was used in measuring other variables. Generally, the items are valid if the reliability coefficient is greater equal to 0.07 and the reliability composite coefficient is greater than 0.7 and the Average Variance Extracted (AVE) is greater than 0.5. Items or dimension with loading factors of less than 0.7 may still be retained in the model if the reliability composite value or AVE is greater than its minimum limit.

Structural model is a model that describe the influence of a variable on other variables in appropriate with research hypothesis. Before conducting an analysis using those two models, we need to check the suitability of the model which is built with data to ensure whether the model is able to describe the phenomena to be examined. 


\section{A. Knowledge Management Variable}

$\mathrm{KM}$ variables were measured using seven dimensions knowledge creation, knowledge retention, knowledge transfer, knowledge utilization, management and leadership support corporate enterpreneurship and application technology. The estimation result of the validity and reliability coefficient for $\mathrm{KM}$ variable is described in the table below.

TABLE II. VALIDITY AND RELIABILITY ANALYSIS OF INDICATORS FROM KNOWLEDGE MANAGEMENT DIMENSION

\begin{tabular}{|l|c|c|c|c|c|}
\hline \multicolumn{1}{|c|}{ Dimension } & $\begin{array}{c}\text { Validity } \\
\text { coefficient }\end{array}$ & $\mathbf{R 2}$ & $\begin{array}{c}\text { Varians } \\
\text { Error }\end{array}$ & $\begin{array}{c}\text { Composite } \\
\text { Reliability }\end{array}$ & $\begin{array}{c}\text { Average } \\
\text { Variance } \\
\text { Extracted } \\
\text { (AVE) }\end{array}$ \\
\hline $\begin{array}{l}\text { Knowledge } \\
\text { Creation }\end{array}$ & 0.78 & 0.6084 & 0.39 & 0.882 & 0.715 \\
\hline $\begin{array}{l}\text { Knowledge } \\
\text { Retention }\end{array}$ & 0.71 & 0.5041 & 0.50 & 0.700 & 0.864 \\
\hline $\begin{array}{l}\text { Knowledge } \\
\text { transfer }\end{array}$ & 0.68 & 0.4624 & 0.54 & 0.848 & 0.650 \\
\hline $\begin{array}{l}\text { Knowledge } \\
\text { utilization }\end{array}$ & 0.80 & 0.6400 & 0.36 & 0.874 & 0.640 \\
\hline $\begin{array}{l}\text { Management and } \\
\text { leadership } \\
\text { support }\end{array}$ & 0.79 & 0.6241 & 0.38 & 0.825 & 0.612 \\
\hline $\begin{array}{l}\text { Corporate } \\
\text { enterpreneurship }\end{array}$ & 0.92 & 0.8464 & 0.15 & 0.831 & 0.622 \\
\hline $\begin{array}{l}\text { Application } \\
\text { technology }\end{array}$ & 0.67 & 0.4489 & 0.55 & 0.841 & 0.639 \\
\hline \multicolumn{7}{|c|}{ Average } & & $\mathbf{0 . 8 2 9}$ & $\mathbf{0 . 6 7 7}$ \\
\hline
\end{tabular}

The composite reliability coefficient of 0.882 states that $88.2 \%$ of knowledge creation changing reflected from the changing of the three items and AVE value of 0.715 states that $71.5 \%$ of the diversity of these three items influenced by knowledge creation dimension.

\section{Industry Environment Variable}

Industry environment variable is measured by using three dimensions, i.e.: the threat of new entrants, consumerôs bargaining power and existing competition intensity. The result of the measurement model is presented as follow:

TABLE III. VALIDITY AND RELIABILITY ANALYSIS OF INDICATORS FROM INDUSTRY ENVIRONMENT DIMENSION

\begin{tabular}{|l|c|c|c|c|c|}
\hline \multicolumn{1}{|c|}{ Dimension } & $\begin{array}{c}\text { Validity } \\
\text { coefficient }\end{array}$ & $\mathbf{R 2}$ & $\begin{array}{c}\text { Varians } \\
\text { Error }\end{array}$ & $\begin{array}{c}\text { Average } \\
\text { Composite } \\
\text { Reliability }\end{array}$ & $\begin{array}{c}\text { Variance } \\
\text { Extracted } \\
\text { (AVE) }\end{array}$ \\
\hline $\begin{array}{l}\text { Threat of new } \\
\text { entrants }\end{array}$ & 0.84 & 0.7056 & 0.29 & 0.880 & 0.698 \\
\hline $\begin{array}{l}\text { Consumerôs } \\
\text { bargaining } \\
\text { power }\end{array}$ & 0.74 & 0.5476 & 0.45 & 0.839 & 0.634 \\
\hline $\begin{array}{l}\text { Existing } \\
\text { competition } \\
\text { intensity }\end{array}$ & 0.71 & 0.5041 & 0.50 & 0.848 & 0.650 \\
\hline \multicolumn{7}{|c|}{ Average } & $\mathbf{0 . 8 5 6}$ & $\mathbf{0 . 6 6 1}$ \\
\hline
\end{tabular}

All the three dimensions of the industry environment variable has validity coefficient greater than 0.700 with composite reliability coefficient greater than 0.700 and AVE value greater than 0:50. It can be summed up that all three dimensions are valid and reliable in measuring industry environment variables.

\section{Competitive Strategy Variable}

Competitive strategy variable is measured with four dimensions, i.e.: overall low cost leadership, differentiation, best cost determination and focus differentiation.

TABLE IV. VALIDITY AND RELIABILITY ANALYSIS OF INDICATORS FROM COMPETITIVE STRATEGY DIMENSION

\begin{tabular}{|l|c|c|c|c|c|}
\hline \multicolumn{1}{|c|}{ Dimension } & $\begin{array}{c}\text { Validity } \\
\text { coefficient }\end{array}$ & $\mathbf{R 2}$ & $\begin{array}{c}\text { Varians } \\
\text { Error }\end{array}$ & $\begin{array}{c}\text { Composite } \\
\text { Reliability }\end{array}$ & $\begin{array}{c}\text { Average } \\
\text { Variance } \\
\text { Extracted } \\
\text { (AVE) }\end{array}$ \\
\hline $\begin{array}{l}\text { Overall low cost } \\
\text { leadership }\end{array}$ & 0.73 & 0.5329 & 0.47 & 0.857 & 0.750 \\
\hline Differentiation & 0.75 & 0.5625 & 0.44 & 0.859 & 0.753 \\
\hline $\begin{array}{l}\text { Best cost } \\
\text { determination }\end{array}$ & 0.73 & 0.5329 & 0.47 & 0.858 & 0.752 \\
\hline $\begin{array}{l}\text { Focus } \\
\text { differentiation }\end{array}$ & 0.75 & 0.5625 & 0.44 & 0.861 & 0.755 \\
\hline \multicolumn{7}{|c|}{ Average } & & $\mathbf{0 . 8 5 9}$ & $\mathbf{0 . 7 5 3}$ \\
\hline
\end{tabular}

Those four dimensions have validity coefficient greater than 0.700 and the value of the composite reliability and the AVE value is also greater than the its minimum limit, thus it can be concluded that those four dimensions are valid and reliable.

\section{Partnership Strategy Variable}

Partnership strategy variable is measured with four dimensions, i.e.: cooperation to improve resource, cooperation with shared-risk, cooperation to improve skills and cooperation to shorten learning process.

TABLE V. VALIDITY AND RELIABILITY ANALYSIS OF INDICATORS FROM PARTNERSHIP STRATEGY DIMENSION

\begin{tabular}{|l|c|c|c|c|c|}
\hline \multicolumn{1}{|c|}{ Dimension } & $\begin{array}{c}\text { Validity } \\
\text { coefficient }\end{array}$ & $\mathbf{R 2}$ & $\begin{array}{c}\text { Varians } \\
\text { Error }\end{array}$ & $\begin{array}{c}\text { Composite } \\
\text { Reliability }\end{array}$ & $\begin{array}{c}\text { Average } \\
\text { Variance } \\
\text { Extracted } \\
\text { (AVE) }\end{array}$ \\
\hline $\begin{array}{l}\text { Cooperation to } \\
\text { improve } \\
\text { resources }\end{array}$ & 0.87 & 0.7569 & 0.24 & 0.861 & 0.755 \\
\hline $\begin{array}{l}\text { Cooperation } \\
\text { with shared-risks }\end{array}$ & 0.77 & 0.5929 & 0.41 & 0.866 & 0.764 \\
\hline $\begin{array}{l}\text { Cooperation to } \\
\text { improve skills }\end{array}$ & 0.73 & 0.5329 & 0.47 & 0.876 & 0.780 \\
\hline $\begin{array}{l}\text { Cooperation to } \\
\text { shorten learning } \\
\text { process }\end{array}$ & 0.74 & 0.5476 & 0.45 & 0.854 & 0.745 \\
\hline \multicolumn{7}{|c|}{ Average } & $\mathbf{0 . 8 6 4}$ & $\mathbf{0 . 7 6 1}$ \\
\hline
\end{tabular}

All four items have high validity coefficient and reliability that greater than the minimum limit. Those items can be inferred valid and reliable in measuring the cooperation to improve the resource dimensions.

\section{Company Performance Variable}

Company performance is measured using three indicators with first order model. Those three indicators are: company revenue growth, company market share, and the growth rate of consumers. 
TABLE VI. VALIDITY AND RELIABILITY ANALYSIS OF INDICATORS FROM COMPANY PERFORMANCE DIMENSION

\begin{tabular}{|c|c|c|c|c|c|}
\hline Dimension & $\begin{array}{c}\text { Validity } \\
\text { coefficient }\end{array}$ & $\mathbf{R 2}$ & $\begin{array}{l}\text { Varians } \\
\text { Error }\end{array}$ & $\begin{array}{l}\text { Composite } \\
\text { Reliability }\end{array}$ & $\begin{array}{c}\text { Average } \\
\text { Variance } \\
\text { Extracted } \\
\text { (AVE) }\end{array}$ \\
\hline $\begin{array}{l}\text { Companyôs } \\
\text { revenue growth }\end{array}$ & 0.67 & 0.449 & 0.551 & 0.862 & 0.778 \\
\hline $\begin{array}{l}\text { Company market } \\
\text { share }\end{array}$ & 0.71 & 0.504 & 0.496 & 0.756 & 0.754 \\
\hline $\begin{array}{l}\text { The growth rate } \\
\text { of consumers }\end{array}$ & 0.81 & 0.656 & 0.344 & 0.845 & 0.782 \\
\hline \multicolumn{4}{|c|}{ Average } & 0.821 & 0.771 \\
\hline
\end{tabular}

One of the indicators of the company performance is company revenue growth rate which has validity value less than 0.0 .700 is equal to 0.67 . However, the value of composite reliability and AVE is still larger than the minimum limit. This cause the company's revenue growth rate item to be kept retain in the model. The item with the highest validity coefficient is the company's customer growth rate items. This result shows the growth rate of customers most associated with the company's performance.

\section{CONCLUSION}

The result of descriptive analysis of the KM variables, industry environment, competitive strategy, partnership and company performance found that:

1. In general, the coffee companies in Aceh do not have good KM implementation. Sharing knowledge is often carried out through non-formal discussion

- Environmental conditions in Aceh coffee industry can be said to be conducive. The intensity of competition seems to be balanced which is highly determined by the threat of the entry of new entrants that are superior in terms of cost.

- The competitive strategy of the coffee companies in Aceh is still poor. The companies respond to competition by creating differentiated products and services, for example by more interesting packaging, although it does not have significant influence.

- The partnership of coffee company in Aceh is considered to poor. The undergoing cooperation which is now running well is the cooperation with shared-risks.

- In general, the coffee company performance in Aceh also still poor. The tight competition due to the emergence of new businesses with sizeable capital led to divided market share that slowing the growth rate of the company's revenue.

2. Knowledge Management and Industry Environment are partially and simultaneously influence the competitive strategy of coffee company in Aceh. Industry environment provide greater influence on competitive strategy compared to knowledge management.
3. Knowledge Management and Industry Environment are partially and simultaneously influence the partnership of coffee company in Aceh. Industry environment provide greater influence on partnership compared to knowledge management.

4. Knowledge Management and Industry Environment are partially and simultaneously influence the competitive strategy of coffee company in Aceh. Industry environment provides greater leverage to partnership compared to knowledge management.

5. Management and industry environment has an indirect significant influence on coffee company performance in Aceh through competitive and partnership strategy.

\section{References}

[1] M. Gibbert, M. Leibold, \& G. Probst, ñFive Styles of Customer Knowledge Management, and How Smart Companies Use Them to Create Valueò, European Management Journal, 20(5), 2002, pp.459469.

[2] ICO (International Coffee Organisation), Coffee Report, London, 2013.

[3] Ministry of Trade and Industry, http://www.kemenperin.go.id/, 2014.

[4] M. A. Gonzalez-Perez, \& S. Gutierrez-Viana, ñCooperation in coffee markets: the case of Vietnam and Colombiaò, Journal of Agribusiness in Developing and Emerging Economies, 2(1), 2012, pp. 57-73.

[5] G. Probst, A. Schmitt, \& B. Stefano, "Donâ let knowledge walk away: Knowledge retention during employee downsizing", Management Learning, 43.1, 2012, pp. 53-74.

[6] H. J. Smyth, J. Kelsey \& A. Roberts, ñHealth and Safety Maturity in Project Business Culturesò, International Journal of Managing Projects in Business, 5(4), 2012, pp.776-803.

[7] C. W. Choo, ñInformation culture and organizational effectivenessò, International Journal of Information Management, 33(5), 2013, pp.775779.

[8] E. Roberto, P. Kotler, \& H. Hugo.Social marketing. Econ-Verlag, 1991, ISBN 9783430156462.

[9] H. W. Ibrahim \& S. Zailani, ñA review on the competitiveness of global supply chain in a coffee industry in Indonesiaò, International Business Management, 4(3), 2010, pp. 105-115.

[10] Badan Pusat Statistik (BPS) Aceh, Aceh dalam Angka 2014, Banda Aceh, 2014

[11] Z. Maryam \& S. Fayezi, ñUnderstanding the Concept of Elasticity in Supply Chain Relationships: An Agency Theory Perspective. Asian Journal on Management Research, Vol. 1, No. 2, 2011, pp. 452-471.

[12] J. M. Whipple, D.F. Lynch, \& G.N. Nyaga (2010). ñA buyer's perspective on collaborative versus transactional relationshipsò, Industrial Marketing Management, 39 (3), 2010, pp. 507.518

[13] R. E. Miles, and C. S. Charles, "Organization theory and supply chain management: An evolving research perspective", Journal of Operations Management, Vol. 25, Issue 2, 2007, pp. 459-463.

[14] J.D. Hunger, T.L Wheelen, Essentials of Strategic Management. Saint Petersburg, Florida: Prentice Hall, 2012, ISBN 978-0136006695.

[15] J. A. Pearce, \& R. B. Robinson, Strategic Management: Formulation, Implementation and Control (13th Edition), New Jersey: McGraw-Hill, 2012, ISBN 978-0078029295.

[16] G. G. Dess, \& J. C. Picken, ñChanging roles: Leadership in the 21 st centuryò, Organizational dynamics, Vol. 28(3), 2001, pp.18-34.

[17] A. Thompson, M. Peteraf, J. Gamble \& A. J. Strickland III, Crafting and Executing Strategy The Quest for Competitive Advantage: Concept and Cases, $17^{\text {th }}$. Edition. The McGraw Hill company, USA, 2010, ISBN 978-0070182608.

[18] M. E. Porter \& D. Esty, ñIndustrial ecology and competitivenessò, Journal of Industrial Ecology, Vol. 1,1998, pp. 34-43.

[19] R. P. U. Beijerse, ñQuestions in knowledge management: defining and conceptualising a phenomenonò, Journal of Knowledge Management, vol. 3, no. 2, 1999, pp. 94-109. 
[20] K. Wiig, ñKnowledge Management for the Competent Enterpriseò, Business Intelligence, Cutter Consortium, Vol. 8, No. 10. 2008.

[21] L.J. Bassi, ñMeasuring Knowledge Management Effectiveness, In J. W. Cortada and J. A. Woods (Eds.), The Knowledge Management Yearbook 1999-2000, Boston MA: Butterworth-Heinemann, 1999, pp. 422-427.

[22] I. Nonaka, ñA dynamic theory of organizational knowledge creationò, Organizational Science, Vol. 5 No. 1, 1994, pp. 14-37. 